\title{
Bringing International Human Rights Law Home: Trends and Practices of Bangladeshi Courts
}

\author{
Sumaiya Khair
}

\section{INTRODUCTION}

The matter of domestic application of international human rights law and standards has traditionally been subject to much debate owing to the seemingly inherent weaknesses of international law in terms of proper enforcement. Indeed, when it comes to the question of compliance with international human rights norms, the track record of many countries falls short of the expected level of observance. This largely proceeds from the stereotypical distinctions made between the significance of municipal law vis a vis international law. Undeniably, there exist differences between international law and municipal law but these differences tend to be exaggerated in ways that trigger conflicting views on the relationship between international law and municipal law and the manner in which courts in domestic jurisdictions may draw on, interpret, and apply principles of international law. While international law essentially focuses on the legal relations between sovereign states, it also confers rights and obligations on individuals, as with human rights, which has considerably eroded the traditional divide between international law and municipal law. This is precisely why it is important to discern how the rules of one system affect the decision-making processes in the courts of another. ${ }^{2}$

The most significant expansion of international law at the end of the World War II has indisputably been in the context of human rights. This is evident not only from the United Nations Charter that proclaims in its Preamble that "promoting and encouraging respect for human rights and for fundamental freedoms for all without distinction as to race, sex,

1 Of the Board of Editors; Professor, Department of Law, University of Dhaka.

2 Martin Dixon, Textbook on International Law 82 (4th ed. 2000). 
language or religion" is a primary purpose of the United Nations, but also from the development of a plethora of international instruments, termed varyingly as treaties, conventions, and covenants, relating to key areas of human rights. These developments essentially paved the way for international oversight of the manner in which states treated their citizens. Accordingly, the Vienna Declaration and Programme of Action (Part I, para. 5$)^{3}$ resolved that

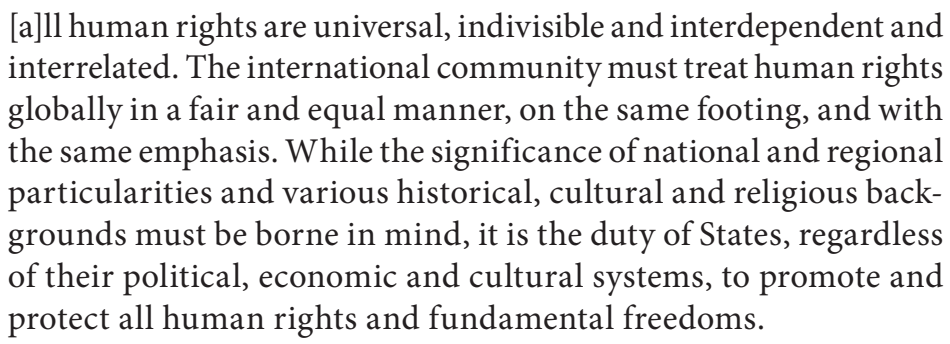

The importance of international human rights gradually percolated down to national legal systems to the extent that the constitutions of many countries embody, in explicit terms, core human rights principles. Notwithstanding, states have historically been reticent to adopt and conform to international law principles ostensibly on the ground that they would compromise national interests and state sovereignty. This attitude of states is derived from the principle of self-government, which recognises that human beings should be able to determine their beliefs, status and outcomes for themselves in a deliberative and participatory fashion, rather than submitting to external forces. ${ }^{4}$ In the context of national rights legislation, self-government would signify that, ultimately, "we have the power to determine for ourselves which purported human rights we recognize, and, by extension, what conception of personhood we hold." 5

The need for interaction between the universality of human rights and particularity of human rights cannot be ignored since the moral universality of human rights, codified in a set of authoritative international norms,

\footnotetext{
3 World Conference on Human Rights, June 14-25, 1993, Vienna Declaration and Programme of Action, Ch. III 5, U.N. Doc. A/CONF/157/23 (October 13, 1993).

$4 \quad I d$. at 263.

$5 \quad I d$. at 264.
} 
can only be realised through the particularities of national action. ${ }^{6}$ Indeed, legal systems globally are more receptive of customary international law as evident from the unequivocal integration of international human rights in many national constitutions. While debates and dissent over the "universality" of human rights have by no means reached a consensus, courts across the world generally acquiesce to those international human rights that are less contentious, for example, the right to life and liberty, freedom from torture, and so on. Despite apparent progression in internationallaw-based judicial thinking and action, there is no reason to think that national courts readily recognise and adhere to international human rights standards; in fact, the tendency by national courts, particularly in dualist systems like Bangladesh, to regard international human rights law as being merely "inspirational" or "persuasive" persists. This trend essentially detracts from the value and effectiveness of international human rights law in the realm of domestic rights adjudication. The present paper posits this argument against the backdrop of the trends and practices of the Bangladeshi Courts in invoking international human rights law. In so doing, the paper briefly draws upon prevalent theories impinging on the domestic application of international law, discusses the status of international law in the Constitution of Bangladesh, and looks at relevant case law in an attempt to assess judicial stance, both progressive and conservative, in invoking international human rights law domestically.

\section{DOMESTIC APPLICATION OF INTERNATIONAL LAW: REVISITING COMPETING THEORIES}

It is generally accepted that principles of international law, whether customary or treaty-based, are normative by character and are binding on states. Nonetheless, controversies persist over the degree and extent to which these norms may be invoked and enforced. There are two dominant theories regarding the application of international law: monism and dualism. The monism theory views both international law and national law as driving from a single body of "law" of which the international and national versions are merely particular manifestations. Accordingly, Monists advocate for the

6 Jack Donnelly, Universal Human Rights in Theory and Practice 181 (2d ed. 2003). 
direct application of international law in state territories through domestic courts and maintain that where there is a conflict between international law and municipal law, the former shall prevail. While there are varying views as to why international law is superior to national law, ${ }^{7}$ there is a consensus that international law and national law are part of the same hierarchical legal order, which demands that they be ranked in order of priority in the event of a conflict. In practice, this denotes that where rights and obligations under national laws do not conform to international law, national courts should give priority to international law over domestic laws. The dualism theory regards international law and national law as two distinct systems, different from each other in terms of characteristics, application procedures, and enforcement mechanisms. For dualists, international law regulates the relations between states on an international level, whereas national law regulates rights and obligation of individuals within a state, internally. As such, under this theory, international law cannot possibly be applied directly by national courts in state territories and are not locally binding unless specifically incorporated in national laws.

Theoretically, national courts may apply rules of international law by way of what is termed as the doctrines of incorporation and transformation. According to the doctrine of incorporation, a rule of international law becomes part of the national law without being expressly adopted by the legislature or the local courts, unless clearly precluded by some provision of the national law whether by statute or judicial decision. In other words, once it is established by the national court that a rule of international law exists that is relevant to the case in hand, the doctrine of incorporation enables it to automatically take recourse to it. This practice, a manifestation of the monist approach, and often referred to as "self-executing," enables courts to "give effect" to an international obligation 'directly', without an

7 According to Hans Kelsen, a noted legal theorist and monist-positivist, international law derives validity from the practice of states whereas national law derives from a state which is established in international law; therefore, international law is superior. Hersch Lautherpacht, a former judge of the International Court of Justice (ICJ), considers international law as higher because it guarantees individual liberty whereas national law cannot be entrusted with the protection of individuals as it, more often than not, persecutes them. Monist-naturalists believe that international law and municipal law are part of a hierarchy of legal orders, with natural law on the top, followed by international law, followed by national law. 
intervening legislation. ${ }^{8}$ The giving of "direct effect" to a rule of international law however does not imply that a court applies an international obligation independently of domestic law or that a provision that has direct effect is superior to national law. What is meant by "direct effect" is that the enforcement of an international obligation is not dependent on subsequent legislation that makes that particular obligation part of domestic law. ${ }^{9}$

The doctrine of transformation on the other hand, strictly dualist in nature, requires that rules of international law to be specifically adopted by the state in an appropriate manner, as by way of an enabling legislation. Therefore, under this doctrine, unless a rule of international law has been legally transformed into national law by deliberate inclusion, it cannot be used by the national courts.

Legal scholarship on the two doctrines demonstrates a preference for the doctrine of incorporation for apparently practical considerations. Shaheed Fatima sums this up based on various judicial observations:

[s] uppose that a rule of customary international law is proved and accepted into domestic law. Once it is part of domestic law, the doctrine of transformation subjects it to the usual domestic rules of stare decisis, i.e. the rule of customary international law must continue to be applied by lower courts until overruled or changed by a court at the same/higher level than the one initially accepting it into domestic law. By comparison, the doctrine of incorporation does not subject rules of customary international law accepted as part of domestic law to the rules of precedent. It permits changes in international law to be reflected in domestic law without first requiring the previous law to be overruled. This flexibility commends the doctrine of incorporation $\ldots{ }^{10}$

Arguably, attempts to address dilemmas over enforcement of international law simply on the basis of the above-mentioned theories can be problem-

8 See G. Sperduti, Dualism and Monism: A Confrontation to be Overcome, 3 Italian Yearbook of International Law 31, 35 (1977); Thomas Buergenthal, SelfExecuting and Non-Self-Executing Treaties in National and International Law, 235 Recueil des Cours 303, 317 (1992).

9 Andre Nollkaemper, National Courts and the International Rule of LAW 120 (2011).

10 Shaheed Fatima, Using International Law in Domestic Courts 408 (2005) (drawing on Lord Denning in Trendtex Trading Corp. v. Cent. Bank of 
atic as national legal systems increasingly have to grapple with emerging exigencies wrought by globalisation. Instead, regard has to be had to the legally binding nature of customary or treaty norms, and incurring state obligations. ${ }^{11}$ Once a treaty enters into force, States Parties are duty bound to fulfill the obligations accruing under them. Clearly, a state cannot violate international law under cover of the existence or non-existence of national law. For instance, "[a state] may not invoke the provisions of its internal law as justification for its failure to perform a treaty"12 nor may it rely on non-compliance with national law in order to deny that it has consented to be bound by a treaty. ${ }^{13}$ Similarly, in the Alabama Claims Arbitration (1872), Great Britain could not take refuge in the absence of domestic law for the non-fulfillment of its obligations of neutrality in the American Civil War. In other words, where there exists binding international obligation, a state must discharge its obligation under it, irrespective of whether its national law permits it or not. ${ }^{14}$ If it is necessary to make a new law or amend an existing law for ensuring compliance, then the state must do so pursuant to its international duty. This is essentially premised on the presumption of international legality which is a rule of legal interpretation whereby domestic law is read, wherever possible with international law and comity. As pointed out by Estey J. in Spencer v. The Queen ${ }^{15}$

'Comity' ... is the recognition which one nation allows within its territory to the legislative, executive or judicial acts of another nation, having due regard both to international duty and convenience,

Nigeria,[1977] 1 Q.B. 529 (C.A.), 533, 554; Stephenson LJ quoting from Lord Alverstone in West Rand Cent. Gold Mining Co. v. The King, [1905] 2 K.B. 391 at 406-08 and Lord MacMillan in Compania Naviera Vascongado v. SS Christina, [1938] A.C. $485,497$.

11 M. Shah Alam, Enforcement of International Human Rights Law by Domestic Courts: A Theoretical and Practical Study, 53 Netherlands International LaW Review 399 (2006).

12 Vienna Convention on the Law of Treaties art. 27, May 23, 1969, 1155 U.N.T.S. 331.

13 Id. at art. 46; see also Maritime Delimitation and Territorial Questions between Qatar and Bahrain (Qatar v. Bahr.), 1994 I.C.J. 112 (July 1).

14 Dixon, supra note 2, at 86.

15 Spencer v. The Queen, [1985] 2 S.C.R. 278 (Can.). 
and to the rights of its own citizens or of other persons who are under the protection of its laws.

In other words, it is incumbent upon states to read domestic law in a manner that does not breach international law. While the rights in question must already be a part of domestic law, their nature and scope may be affected by customary international law. For example, while recognising that that the parliament can, if it chooses, legislate contrary to fundamental principles of human rights, Lord Hoffmann in Regina v. Secretary of State for the Home Department, Ex Parte Simms ${ }^{16}$ observed that

the principle of legality means that Parliament must squarely confront what it is doing and accept the political cost. Fundamental rights cannot be overridden by general or ambiguous words. This is because there is too great a risk that the full implications of their unqualified meaning may have passed unnoticed in the democratic process.

Violations of international law and comity by unlawful constructions of domestic law may incur international responsibility for the concerned state unless the legislature clearly expresses its intention for doing so and the reasons underlying it. ${ }^{17}$

\section{INTERNATIONAL LAW AND THE CONSTITUTION OF BANGLADESH}

The war of liberation in 1971, which was fought to secure the right to selfdetermination, essentially marks the beginning of human rights activism in Bangladesh. Within one year of its independence, the newly emerged country applied for membership at the United Nations. On 17 September 1974, Bangladesh became the $136^{\text {th }}$ member of the United Nations and as such, adhered to the 1948 Universal Declaration of Human Rights (UDHR). ${ }^{18}$ Indeed, Bangladesh's commitment to UDHR specifically, and

16 Regina v. Sec'y of State for the Home Dep't, Ex Parte Simms, [2000] 2 A.C. 115 (H.L.) 131E-G, in Shaheed, supra note 10, at 217-18.

17 Gibran van Ert, Using International Law in Canadian Courts 100 (2002).

18 The UDHR is recognised as a statement of general principles expounding the meaning of the phrase "human rights and fundamental freedoms" envisaged in the U.N. Charter. For more, see Louis Sohn, A Short History of United Nations 
international law obligations generally, is manifest from the Preamble of the Constitution of the People's Republic of Bangladesh ${ }^{19}$ which pledges that

it shall be a fundamental aim of the State to realise through the democratic process to socialist society, free from exploitation-a society in which the rule of law, fundamental human rights and freedom, equality and justice, political, economic and social, will be secured for all citizens;

...[I]t is our sacred duty. . . [to] make our full contribution towards international peace and co-operation in keeping with the progressive aspirations of mankind.

The act of ratifying or acceding to a given international Convention essentially demonstrates a State's willingness to adhere to the provisions envisaged in that Convention. Bangladesh has ratified or acceded to almost all key international human rights instruments, namely:

- International Convention on the Elimination of All Forms of Racial Discrimination (1965)

- International Convention on the Suppression and Punishment of the Crime of Apartheid (1973)

- Convention on the Elimination of all Forms of Discrimination against Women (1979) and its Optional Protocol (2000)

- Slavery Convention (1926)and the Protocol a mending the Slavery Convention (1953)

- Supplementary Convention on the Abolition of Slavery, the Slave Trade and Institutions and Practices Similar to Slavery (1956)

- Convention for the Suppression on Traffic in Persons and of the Exploitation of the Prostitution of Others (1949)

- Convention on the Rights of the Child (1989) and its two Optional Protocols (2001)

Documents on Human Rights, in Commission to Study the Organization of Peace, United Nations and Human Rights 71 (1968).

19 Bangladesher Shongbidhan [Bangl. Const.] Nov. 4, 1972, preamble (Bangl.). 
- International Covenant on Economic, Social and Cultural Rights (1966)

- Convention on the Prevention and Punishment of the Crime of Genocide (1948)

- Convention on the Political Rights of Women (1952)

- Convention on Consent to Marriage, Minimum Age for Marriage and Registration of Marriages (1962)

- Convention against Torture and other Cruel, Inhuman or Degrading Treatment or Punishment (1984)

- Convention on the Rights of Persons with Disabilities 2006 and its Optional Protocol

- Convention against Corruption (2003)

- $\quad$ Rome Statute of the International Criminal Court (1998)

- International Convention on the Protection of the Rights of All Migrant Workers and Members of their Families (1990)

Bangladesh is also party to a number of core International Labour Organization (ILO) Conventions that impinge on human rights. These include:

- $\quad$ Forced Labour Convention (No. 29) (1930)

- $\quad$ Convention on the Right to Organize (Agriculture) (No. 11) (1921)

- Convention on the Right to Freedom of Association and Protection of the Right to Organize (No. 87) (1948)

- Convention on the Right to Organize and Collective Bargaining (No. 98) (1949)

- Convention on the Elimination of Worst Forms of Child Labour (No. 182) (1999)

The Constitution of Bangladesh, adopted in 1972 and amended from time to time, acts as a bulwark against abuse of civil and political rights. It provides fundamental rights that guarantee inter alia equality before law and equal protection of law, protection of life and liberty, and prohibits discriminatory treatment and forced labour. The Constitution also guarantees rights 
during arrest, detention, trial, and punishment. Specific liberties of speech and expression, movement, association and assembly, trade and occupation, religion and property, security of home, and privacy are also guaranteed.

Article 26 of the Bangladesh Constitution ${ }^{20}$ declares all existing laws inconsistent with the provisions of the fundamental rights as void on and from the day of the commencement of the Constitution. Furthermore, Article 26(2) divests the legislature of the power to make a law that is inconsistent with the fundamental rights; in the event such laws are passed they shall be void to the extent of such inconsistency. Therefore, Article 26 does not declare such laws void from their inception, rather from the day the Constitution comes into force. Article 26 is premised on the doctrines of eclipse and severability. It is said that a law that was valid at its inception but subsequently becomes void for its contradiction with any constitutional provision, is "eclipsed" in the sense that such a law does not die but remains dormant and revives upon removal of the contradiction. ${ }^{21}$ Where a law has several parts and if any one part, but not all, becomes void on for contradicting the provisions of the constitution, then only the part that is inconsistent shall be declared void and not the whole law. This is known as the doctrine of severability. ${ }^{22}$ Thus, Article 26, by declaring that a law inconsistent with the fundamental rights shall be void, acknowledges that the rest of the law shall be valid as has been enacted.

The Constitution also sets out the fundamental principles of state policy which require the State to ensure inter alia women's participation in national life, free and compulsory education, public health, equality of opportunity, work as a right and duty, rural development and promotion of local government institutions, and respect for international law. Although theoretically considered to be judicially unenforceable, ${ }^{23}$ the Supreme Court

20 BAngl. Const., art. 26.

21 Muhammad Ekramul Haque, Protection of Fundamental Rights through Restricted Legislative Competence: Application of the Doctrine of Eclipse and Severability, 17 Journal Of the Faculty of Law, Dhaka University Studies, Part F 49, 58 (2006).

22 Id. at 59.

23 BAngl. Const., art. 8(2). 
has, on a number of occasions, upheld these fundamental principles in protecting economic and social rights of citizens.

While the Constitution prima facie takes a proactive view of human rights and civil liberties, it does not, however, clearly explain the status of international law in the domestic legal system, nor does it explicitly require or direct the judiciary to draw on international human rights law when adjudicating cases. It merely alludes narrowly to "international relations" and obligations pertaining thereto as envisaged in Article 25, which reads:

The State shall base its international relations on the principles of respect for national sovereignty and equality, noninterference in the internal affairs of other countries, peaceful settlement of international disputes, and respect for international law and the principles enunciated in the United Nations Charter, and on the basis of those principles shall

(a) strive for the renunciation of the use of force in international relations and for general and complete disarmament;

(b) uphold the right of every people freely to determine and build up its own social, economic and political system by ways and means of its own free choice; and

(c) support oppressed peoples throughout the world waging a just struggle against imperialism, colonialism or racialism. ${ }^{24}$

While respect for International Law has been briefly referred to in Article 25 above, there is a certain vagueness which, in essence, generates diverging views on the appropriateness of applying international law norms in domestic contexts. A liberal interpretation of the Constitutional provisions as envisaged in the Preamble and Article 25 respectively would be that these provisions together do, in essence, embody and give constitutional effect to certain international law norms; contrarily, a conservative interpretation may very well disagree with this view on the basis of Article 8(2) of the Constitution, which declares that Article 25 cannot be judicially enforced. ${ }^{25}$

24 BAngl. Const, art. 25.

25 Ridwanul Hoque \& Mostafa M. Naser, The Judicial Invocation of International Human Rights Law in Bangladesh: Questing a Better Approach, 46 Indian Journal of InTERnational LaW 151, 160 (2006). 
In attempting to reconcile the two competing views, it may be argued that notwithstanding the non-justiciability of the Fundamental Principles of State Policy and as such, Article 25, the Constitution nevertheless explicitly recognises that they are fundamental to the governance of Bangladesh and its law making process as well as a guide to the interpretation of the Constitution and other laws. It may be deduced from this that the judiciary is free to rely on and refer to international law in the interpretation and application of national laws to the extent possible.

The constitutional position on treaties is also not straightforward. Article 145A of the Bangladesh Constitution states that "all treaties with foreign countries shall be submitted to the President, who shall cause them to be laid before the Parliament." ${ }^{26}$ A proviso to this article requires that "any such treaty connected with national security shall be laid in a secret session of the Parliament." 27 These provisions are steeped in ambiguities regarding for example, what treaties would fall within the ambit of Art. $145 \mathrm{~A}$ and what procedure does the Constitution prescribe before ratification of a treaty in order to bind the state?

It is not clear from the wording in the Constitution as to what treaties would be construed as coming within the purview of the Article 145A. This gives rise to varying interpretations. Huda and Hasan, in their research, underscore several interpretations from their discussions with a cross-section of judges, lawyers and legal academics. ${ }^{28}$ Some favour a strict interpretation of Article 145A of the Constitution and maintain that Article $145 \mathrm{~A}$ by only referring to "treaties with foreign countries" precludes trade or commercial treaties, treaties with International Organizations, and International Conventions. Some surmise that Article 145A refers mainly to agreements whereby the conduct of parties is determined or which imposes on them legal duties. For others, the literal meaning of this Article appears to include bilateral, regional, and multilateral treaties. According to

26 BAngl. Const., art. 145A.

27 A proviso was first added to Article 145A by way of the Constitution (Twelfth Amendment) Act 1991 which stated that "Provided that no such Treaty shall be so laid if the President considers it to be against the national interest so to do." This was subsequently altered to the current form by the Constitution (Fifteenth Amendment) Act 2011.

28 Shahnaz Huda \& Manzoor Hasan, The Bangladesh Parliament and InTERNATIONAL CONVENTIONS 33-35 (2000). 
Mahmudul Islam, a constitutional law expert, all agreements entered into by Bangladesh with foreign countries are not treaties within the meaning of Article 145A; only those agreements, whether called treaty, convention, covenant, protocol, charter or exchange of notes, concluded with foreign countries in written form and governed by international law, are treaties within the meaning of this Article. Islam adds that in a treaty, there has to be an intention to create a legal obligation, which must be governed by international law and not municipal law. ${ }^{29}$

The Constitution is silent on the issue of treaty ratification process. It may be pointed out that Article 145A only speaks of the President "laying" treaties before the Parliament but there is no reference whatsoever to the act of ratification. Whether the term 'laying' has been used synonymously to mean "ratification" is likewise not clear. This ambiguity was addressed in the case of Kazi Mukhlesur Rahman v. Bangladesh, ${ }^{30}$ more commonly known as the Berubari case, where the Court held that "treaty making is an executive act and so also ratification if a Treaty contains provisions for ratification and that both fall within the ambit of the executive power of the State." In practical terms, however, while theoretically treaties are a prerogative of the Executive, all actions relating to treaty-making are determined by the Prime Minister and the Cabinet. This is evident from Article 55(2)(4) of the Constitution which states that the "executive power of the Republic shall ... be exercised by or on authority of the Prime Minister," although "[a]ll executive actions of the Government shall be expressed to be taken in the name of the President." Besides, the Rules of Business of the Government 1996 require all draft agreements, protocols, and treaties to be submitted to the Cabinet, which is headed by the Prime Minister, for approval.

Again, although a plain reading of Article 145A indicates that the President has an important role in the ratification of a treaty as he is required to place it before the Parliament, this is not actually so as the said provision has arguably been framed in the interest of deliberation and for ensuring transparency in the process of vetting and entering into a treaty

29 Mahmudul Islam, Constitutional Law of BAngladesh 734-35 (2d ed., 2002).

30 Kazi Mukhlesur Rahman v. Bangladesh and others, 26 DLR (1974) (SC) 44. In this case a writ petition was filed challenging the constitutional validity of the Delhi Treaty entered into by Bangladesh and India relating to the transfer of Berubari enclave involving the cession of Bangladesh territory. 
rather than ratification of a treaty. As observed by the High Court Division of the Supreme Court of Bangladesh in the case of Major (Retd.) Akhtaruzzaman $v$. Bangladesh, ${ }^{31}$ though there is an obligation to lay a treaty before the Parliament, failure to do so will not affect its validity. However, if the performance of treaty obligations requires the alteration of any existing law, an Act has to be passed by the Parliament to that effect.

Similarly, changes in national boundary require Parliamentary sanction as clearly directed in Kazi Mukhlesur Rahman v. Bangladesh. ${ }^{32}$ It is obvious from the foregoing discussion that the Parliament does have significant powers of oversight, if not of direct ratification, of a treaty.

\section{EMPLOYING INTERNATIONAL HUMAN RIGHTS LAW: CONSERVATIVE JUDICIAL PRACTICE}

Progressive thinking on the part of the judiciary in Bangladesh in utilizing international human rights law is more often than not the exception rather than the rule. Although the mode of enforcement of international human rights law is not clear from the Constitution, it is common for courts in Bangladesh to rely on the principle that customary international law cannot supersede statute law. Accordingly, the courts have no power to enforce treaty rights and obligations at the behest of a sovereign government or a private individual unless the treaty becomes incorporated into the laws of Bangladesh by an Act of Parliament. ${ }^{33}$

There are a number of cases that demonstrate judicial passivism when it comes to taking recourse to international law despite recognition and respect for it by the Court. Instead, where there is a domestic law in place that is pertinent to the dispute, the Court gives effect to the domestic law and not to customary international law. In the case of $M / s$. Supermax

31 Writ Petition No. 3774 of 1999 (unreported), in IsLAM, supra note 24, at 735.

32 The Court held that "though treaty-making falls within the ambit of the executive power under Article 55(2) of the Constitution, a treaty involving determination of boundary, and more so involving cession of territory can only be concluded with the concurrence of Parliament by necessary enactment ...." Kazi Mukhlesur Rahman v. Bangladesh and others, 26 DLR (SC) (1974) 44. 
International Private Ltd. v. Samah Razor Blades Industries, ${ }^{34} \mathrm{Mr}$. Justice Mohammad Fazlul Karim observed:

Though International Convention . . . could be recognized upon ratification but could only be applied in our Country only when its provisions are incorporated in our Municipal laws and thus for enforcing any International Covenants under any Convention to which this Country is a signatory, the provisions of the Convention have to be incorporated in our domestic law.

This approach is also seen in the case of Bangladesh v. Sombon Asavhan, ${ }^{35}$ which addressed the question whether Thai fishing trawlers, captured by the Bangladesh Navy for illegally entering and fishing in the territorial waters of Bangladesh, were actually within the territorial waters or the exclusive economic zone of Bangladesh. Instead of resorting to existing international law relating to territorial waters, the Appellate Division of the Supreme Court settled the matter on the basis of The Bangladesh Territorial Waters and Maritime Zones Act 1974. The Court observed in precise terms:

It is well settled that where there is municipal law on an international subject the national court's function is to enforce the municipal law within the plain meaning of the statute .... [T] he point touches international law since three fishing trawlers are involved and they are captured from a place over which Bangladesh claims sovereignty. We are relieved from entering into long discussion of diverse laws, conventions, rules and practices of international law since there is [a] complete code provided by our municipal law. ${ }^{36}$

The Court explained that the Parliament adopted The Bangladesh Territorial Waters and Maritime Zones Act 1974 pursuant to the power given by Article 143(I)(B) of the Bangladesh Constitution and accordingly, in practice, the court follows the domestic law when such a law on a given issue exists. It added that "this strictness in following the state law imposes cer-

\footnotetext{
34 M/s. Supermax International Private.ate Ltd. v. Samah Razor Blades Indus. Ltd., $2 \operatorname{ADC}(2005)$ 593, at 600.

35 Bangladesh v. Sombon Asavhan, 32 DLR (1980) (SC) 194, at 197-8.

36 Id. at 201-02.
} 
tain amount of responsibility on the lawmakers not to make laws as would encroach upon the accepted boundaries of the international community." ${ }^{37}$

In the case of Saiful Islam Dildar v. Government of Bangladesh and others ${ }^{38}$ the High Court Division of the Supreme Court took into account the issue of the right to self-determination under customary international law vis a vis the provisions of the Bangladesh Constitution. In this case a writ was filed challenging the Bangladesh Government's readiness to extradite Anup Chetia, Secretary General of the United Liberation Front of Assam (ULFA), who was charged with treason by the Government of India. The Petitioner on behalf of Chetia contended that the latter was fighting for the right of self-determination by the people of Assam, and as such his extradition would not only contravene the peremptory norm of jus cogens in international law, but would also violate principles of human rights law and Article 25 of the Bangladesh Constitution. The Petitioner further argued that the right to self-determination as jus cogens of international law has not only been incorporated into the major human rights instruments and the U.N. Charter but has also become a universally acceptable customary norm which was binding upon all nations. Consequently, Bangladesh had an obligation to accord refugee status to Chetia. The Court took a rather conservative view of the arguments and the reference to customary international law, and rejected the petitioner's contention that the extradition of Chetia would violate Article 25 of the Constitution. On the contrary, the learned Court held that the extradition of Chetia would, in fact, be

in consonance with the Principles of State Policy and help base its international relations on the principles of respect for national sovereignty and equality, non-interference in the internal affairs of other countries .... Article 25(1)(c) enjoins upon the state to support throughout the world waging a just war against imperialism, colonialism or racialism. We are afraid to accept the contention that as because Anup Chetia is struggling for "self-determination" for the people of Assam, handing him over to India would be violative of Article 25 of our Constitution. The struggle in which ULFA and its Secretary General Anup Chetia is involved is not, in our opinion, "waging a just struggle against imperialism, colonialism or racialism" ... Nor can it be said that the right to "self-determination" as

37 S.M. Hussain \& M.M. Haque, Status of International Law in Bangladesh Courts, 7 LaW and International Affairs 71 (1984).

38 Saiful Islam Dildar v. Bangladesh and others, 50 DLR (1998) 318. 
canvassed in this petition falls within any of the three expressions viz. "imperialism", "colonialism" or "racialism" as used in Article 25(1)(c) of the Constitution. ${ }^{39}$

The manner in which the Court in this case relied on the Constitutional provisions to counter the petitioner's claim clearly indicates the Court's reluctance to utilize customary international law for progressive interpretation of the national laws or bring about changes to municipal law.

In the case of M. Saleem Ullah v. Bangladesh, ${ }^{40}$ the Petitioner similarly relied on Article 25(1) of the Constitution and the peremptory norm of jus cogens to argue that the decision of the Bangladesh Government to participate in the U.N. sponsored multinational force to Haiti for restoration of the legitimate government there was illegal, as the military operation was in fact a U.S. led aggression. The Petitioner also stated that the government decision violated Article 63 of the Constitution under which only the President is empowered to declare war with the assent of the parliament. The Court observed that the government decision to participate in such a mission was taken pursuant to U.N. Resolution No. 940 and Bangladesh being a member state had taken the decision on the authority of the constitutional framework and international commitment. In the Court's view, the decision was therefore not derogatory to any provision of the Constitution including the Fundamental Principles of State Policy. While the Court in this instance was apparently mindful of state obligations under the U.N. Charter, it virtually ignored the commitments and obligations of Bangladesh under customary international law and treaties to which it is party. This demonstrates the trend of selective implementation of international law by courts in Bangladesh.

In the case of Hussain Muhammad Ershad v. Bangladesh and Others, ${ }^{41}$ the Court recognized that although Universal Human Rights norms envisaged in the UDHR or in the Covenants are not directly enforceable in national courts, their provisions, if incorporated into the domestic laws, are enforceable by local courts. The Court conceded that the local laws, whether constitutional or statutory, are not always in consonance with international human rights instruments. Nonetheless, domestic courts

39 Id. at $322-23$

40 M. Saleem Ullah v. Bangladesh., 47 DLR (1995) 218.

41 Hussain Muhammad Ershad v. Bangldesh, 21 BLD (AD) (2001) 69. 
should not outright ignore international obligations of the country; rather, if the national laws are unclear or devoid of a specific provision, the national courts should draw upon relevant principles enshrined in international instruments. However, where domestic laws are clear but inconsistent with international obligations of the state, the national courts, while obliged to respect the national laws, will draw the attention of the lawmakers to such inconsistencies. The Supreme Court expressed similar views in the cases of Bangladesh v. Sheikh Hasina ${ }^{42}$ and State v. Metropolitan Police Commissioner. ${ }^{43}$

These various instances amply demonstrate the persistence with which the courts in Bangladesh have refrained from invoking international law principles in judicial reckoning. Indeed, the potential of international law norms in enhancing the effectiveness of domestic rights adjudication have largely been sidelined by the courts' obstinate endorsement of the dualist approach to international human rights treaties.

\section{THE APPLICATION OF INTERNATIONAL HUMAN RIGHTS LAW: PROGRESSIVE JUDICIAL PRACTICE}

The Supreme Court of Bangladesh has, on different occasions, formally recognized customary international law and interpreted state obligation under it. In one of its early decisions in the case of Bangladesh v. Unimarine S.A. Panama ${ }^{44}$ the Court conceded that customary international law is binding on States and States generally give effect to rules and norms of customary international law. This line of judicial reasoning has subsequently been reaffirmed in other cases. However, the use of international law by Bangladeshi courts is largely restricted to supplementing judicial observations, analyzing provisions of the law and the constitution, and generally embellishing the court's decision. An attempt is made here to

42 Bangladesh. v. Sheikh Hasina, 60 DLR (AD) (2008) 104.

43 State v. Metro. Police Comm'r, 60 DLR (AD) (2008) 660.

44 Bangladesh v. Unimarine S.A. Panama, 29 DLR (1977) (AD) 252. The question that arose in this case was whether private foreign companies could enjoy immunity from arrest and seizures. The Court held that foreign companies did not qualify for such protection as the rules of immunity only pertained to person or property of foreign missions and diplomatic envoys under public international law. 
encapsulate specific examples of judicial consideration of international law in interpreting legal and constitutional provisions.

\section{a. Children's Rights}

The courts in Bangladesh have been found to be particularly flexible in the use of the principles of international human rights law while adjudicating cases involving children. The following instances illustrate the latitude exercised by the courts in referring to international human rights law when deciding matters impinging on children.

\section{CHILD CUSTODY}

A scrutiny of child custody cases reveals how courts have digressed from conservative interpretations of Muslim laws on custody and instead engaged in a more liberal analysis of the same having due regard to the child's best interests. ${ }^{45}$ In the case of Mst. Sultana Begum v. Muhammad Shafi ${ }^{46}$ it was contended that if the welfare of the child lies predominantly elsewhere and awarding of custody in conformity with the dictates of the personal law would in essence be against his/her interest, then the Court must act

45 Muslim Law makes a clear distinction between custody (Hizanat) and guardianship (Wilaya) of children According to the Sunni Hanafi school when a couple separates the mother is entitled to custody of the child. She is so entitled until the child attains puberty in case of girl and 7 years if it is boy. Under Muslim Law a mother can never be the legal guardian; she can only have the child in her custody until it reaches a certain age. This is premised on the understanding that of all the people a mother is by far the most capable of caring for her child. The mother is entitled to this right even if her husband divorces her. However, the right is forfeited if she marries a stranger, i.e., a person who is not barred to the children on grounds of consanguinity, or if she changes her religion. Under the Hanafi Muslim Law the father is the legal guardian of his child. The father is liable to maintain his child even where it is in the custody of the mother following dissolution of the marriage. In the absence of the father the guardianship devolves on the father's executor and in his absence, it vests in the grandfather and in his absence, in his executor in that order of priority. Therefore, the mother is never the legal guardian of her child; she can only be the legal guardian of the minor's property at the death of the father and that too, if she is so appointed by the Court or the father or the grandfather. 
according to the demands of the welfare of the child. Similarly, in Mst. Fahmida Begum v. Habib Ahmed ${ }^{47}$ it was deemed permissible to depart from the rules of Hizanat stated in Muslim Law and grant the mother the custody of the child if the application of such rules went against the interests of the child. In Johara Begum v. Maimuna Khatun ${ }^{48}$ the Court ruled that the mother's right to custody of her minor daughter was not lost simply because she took a second husband following the demise of the child's father on the ground that the child would be better looked after and cared for by the mother than anyone else. In the case of Akhtar Ahmed v. Mst. Hazoor $B e g u m^{49}$ the Court held that the mere fact that the mother has remarried does not finally determine the question of custody of the minor; rather, the welfare of the child would be of paramount consideration.

In $M d$. Abu Baker Siddique v. S.M.A Bakar ${ }^{50}$ the Court granted custody of an eight-year-old boy to the mother who had given up her job in Saudi Arabia to come back home to care for her son. In this case, although the boy had crossed the legal age at which he could remain in the custody of his mother, the Appellate Division of the Supreme Court, after considering all the facts and circumstances, upheld the mother's right to custody. Referring to earlier decisions cited by the Appellant's counsel, the Court observed that "[T]hese decisions, while recognising the principle of Islamic Law as to who is entitled to the custody of a minor son with reference to his or her age and sex. simultaneously took into consideration the welfare of the minor child in determining the question. Courts in all these cases seem[ed] reluctant to give automatic effect to the rules of Hizanat enunciated by Islamic jurists. If circumstances existed which justified the deprivation of a party of the custody of his child to whose custody he was entitled under Muslim Law, Courts did not hesitate to do so... [Thus,] the court's power to determine the entitlement of a party to Hizanat is not limited to mere observance of the age rule so as to exclude the best interests of the child." ${ }^{51}$ The Court asserted that since there is no uniformity amongst different schools of Muslim Law regarding custody, a departure

47 Mst. Fahmida Begum v. Habib Ahmed, 20 DLR (WP) (1968) 254.

48 Johara Begum v. Maimuna Khatun, 16 DLR (1964) 695.

49 Akhtar Ahmed v. Mst. Hazoor Begum, 17 DLR (WP) (1965) 39.

50 Md. Abu Baker Siddique v. S.M.A Bakar, 38 DLR (AD) (1986) 111.

$51 \quad I d$. at 108. 
from the rules of Muslim Law was permissible. In the circumstances, the father's prima facie right to custody of his son could not have any claim to immutability. This indicates that personal laws should not be seen as fixed and defined in perpetuity but should be progressively re-interpreted in certain circumstances.

These various judicial decisions effectively demonstrate a readiness on the part of the learned judges to rely on and give primacy to international law to ensure the well-being of minors, even if entails a compromise with traditional Muslim family laws.

\section{CHILDREN IN CONTACT WITH THE LAW}

Judicial vigilance in applying international human rights law is perceived in cases involving children in the justice system. In one of the landmark cases on juvenile justice, State v. Roushan Mondal Hashem, ${ }^{52}$ the High Court Division embarked on an elaborate discussion on the manner in which children in the criminal justice system should be treated and the rationale underlying it. Referring to various American scholarships and legislation on the subject, the Court reiterated that a child engaged in unlawful activity should not be branded as a "juvenile delinquent" or a "wayward child" and exposed to the "rigours of the criminal justice system with all its awe inspiring paraphernalia and the stigma of criminality at the conclusion of the proceedings that find the child guilty." It acknowledged that the Court or State stands in loco parentis and while ensuring that the unlawful activity of the child does not go unpunished, should adjudge that a child is in need of care and protection. With regard to juvenile trial, the Court observed that

[t] he overall aim [sic] is not punish the offender, but to seek out the root of the problem, in other words, not treating the delinquents as criminals, but treating the cause of their criminality and directing them on a path which will be acceptable to mainstream society in

52 State v. Roushan Mondal Hashem, 59 DLR (2007) (HCD) 72. 
order to ensure their rehabilitation. More so in our case since our penal policy is basically reformative, and not retributive. ${ }^{53}$

The Court further reiterated:

[T]he thrust of the International Declarations, Rules and Covenants and other instruments is towards reformation of youthful offenders and for establishment of facilities for proper education and upbringing of youths so that they are prevented from coming into conflict with the law. In the event that a child or juvenile does come into conflict with the law, then the aim is to provide a system of justice which is 'child friendly' and which does not leave any psychological scar or stigma on the child, an, on the contrary, prepares him for a fruitful future. ${ }^{54}$

In addressing the date relevant for the assessment of the age of the child, the Court observed that

... [i]n view of the international covenants, declarations and other instruments, we feel inclined to the view that the relevant date must be the date on which the offence is committed, otherwise the whole thrust of the law to protect those who are immature, impetuous, unwary, impressionable, young, fickle-minded and who do not now the consequences of their act, would be lost. It is the mental capacity of the offender at the time of committing the offence which is of crucial importance..$^{55}$

The Court emphasized the segregation of children from adult offenders and declared that

... [the] juvenile will get the benefit of all the rights to which he would be entitled had the proceedings taken place in the Juvenile Court. That, we believe, follows the spirit and intendment of the international instruments which crave for the well being of the youthful offender and enjoin segregation of youths from adults at all stages from apprehension to incarceration. ${ }^{56}$

This decision, by its very depth and content, demonstrates the Court's sensitivity to children in the justice system and a keenness to ensure that

$\begin{array}{ll}53 & I d . \text { at } 84 . \\ 54 & I d . \text { at } 85 . \\ 55 & I d \text {. at } 89 . \\ 56 & I d . \text { at } 86 .\end{array}$


these children are treated in accordance with internationally acceptable minimum standards.

In Bangladesh Legal Aid and Services Trust v. Bangladesh and Others, ${ }^{57}$ the petitioner, a legal aid organisation, challenged the continued incarceration of under trial prisoners, including children, for an indefinite period of time without lawful authority. The Petitioner moved the Court following news coverage in a national daily of 155 under trial prisoners who remained in Dhaka Central Jail for up to five years or longer due to prosecution's failure to produce witnesses. The Petitioner alleged that there were other instances of prisoners, including women and children, languishing in jail in different parts of the country. It was asserted that such continued incarceration was without lawful authority and ultra vires relevant provisions of The Criminal Procedure Code 1898, the Constitution, and International Covenant on Civil and Political Rights (to which Bangladesh is Party) pertaining to a person's fundamental rights to personal liberty and speedy trial. Information from the office of the Additional Inspector General of Prison revealed that out of the total under trial prisoners in jail, 214 were children below the age of 18 years. The Court observed that children were entitled to trial before the Juvenile Courts in accordance with the relevant laws and positive steps should have been taken in this case to ensure that children were not tried jointly with adults. It directed that trial, if any, of all juveniles accused be completed expeditiously by the Juvenile Courts and instructed the concerned law enforcing agencies, prosecuting agencies, and Government Legal Aid Committees to take immediate and appropriate steps in this regard. The Court further directed the Government to move the concerned courts to discharge, withdraw or transfer to certified Homes, as the case may be, children accused in appropriate cases. The Legal Aid Committees of the Government were instructed to arrange bail for the children accused. The Court also held that children should be kept separate from other prisoners and should be allowed non-official jail visitors, including human rights activists and representatives of children's organizations.

Similar directions were given by the High Court Division in a suo moto initiative when its attention was drawn to a news item published

57 Bangladesh Legal Aid and Services Trust v. Bangladesh, 57 DLR (HCD) (2005) 11. 
in a national daily which described the plight of nearly 400 children in Dhaka Central Jail. ${ }^{58}$

In the case of State v. Metropolitan Police Commissioner, ${ }^{59}$ the Court observed that the "underlying theme of international Covenants and instruments relating to children is that they are to be enlarged on bail and to be detained only as a last resort." Pursuant to newspaper report on how an 8 year old girl was sent to jail for drug trade, the Court issued a rule nisi calling upon the Respondents to show why the detention in jail of a minor girl should not be declared illegal. The fact of the case in brief was that in 2008, a young girl named Arifa, along with one Ripon, was caught with 29 bottles of addictive substance strapped to different parts of her body. The police seized the incriminating goods in the presence of witnesses and produced both Arifa and Ripon before the Magistrate. It was stated in the First Information Report (FIR) that Arifa was 10 years old. The learned Magistrate nonetheless sent both Arifa and Ripon to jail custody. Subsequently, a prayer for their bail was made but it was opposed by the prosecution and rejected by the Magistrate. Arifa was sent to safe custody. The Court, after perusing though various reports, came to the conclusion that Arifa was 9 years old. It was observed by the Court that "the underlying theme of international Covenants and instruments relating to children is that they are to be enlarged on bail and to be detained only as a last resort ...."While the law provides that if a child who is accused of an offence is not released on bail, the Court should order him/her to be detained in a place of safety, but the question in the present case was whether such a place would be suitable for a 9-year-old girl. The Court observed that

Bangladesh was one of the first signatories to the Convention [on the Rights of the Child] and is bound to take steps for implementing the provisions thereof. Being signatory we cannot ignore, rather

\footnotetext{
58 Suo Moto Order No. 248 of 2003, by J. Amirul Kabir Chowdhury \& J. Nizamul Huq.

59 State v. Metro. Police Comm'r, 60 DLR (HCD) (2008) 660, at 664.
} 
we should, so far as possible, implement the aims and goals of the UNCRC. ${ }^{60}$

The Court referred to the decision of the Indian Supreme Court in People's Union for Civil Liberties v. Union of India, ${ }^{61}$ which essentially maintained that provisions of international covenants and conventions which elucidate and effectuate the fundamental rights guaranteed by the Constitution, can certainly be relied on by national courts.

The Court also drew attention to the decision of the Australian Court in Minister of State for Immigration and Ethnic Affairs v. Teoh, ${ }^{62}$ which stated:

It is well established that a provision of an international treaty to which Australia is a party do not form part of Australian law unless those provisions have been validly incorporated into our municipal law by statute .... [But] the fact that convention has not been incorporated into Australian law does not mean its ratification holds no significance for Australian law.

... The provisions of an international convention to which Australia is a party, especially one which declares universal fundamental rights, may be used by the Courts a legitimate guide in developing the common law.

Drawing upon the above-mentioned decisions, the Bangladesh Court stated:

Let us consider some of the relevant provisions of the UNCRC in juxtaposition to our Constitution and laws. We bear in mind that Article 28(4) of the Constitution permits favourable laws to be enacted with regard to children even though it might be otherwise discriminatory.$^{63}$

The Court accordingly drew extensively on the CRC in order to highlight how the best interests of the child should be invoked in this case. Recognizing that the Children Act 1974 provides for special treatment for children, the Court nonetheless recommended that

... [t]he Legislature should consider amending the Children Act 1974 or formulating new laws giving effect to the provisions of

$60 \quad I d$. at 665 .

61 People's Union for Civil Liberties v. Union of India, (1997) 3 S.C.C. 43 (India).

62 Minister of State for Immigration and Ethnic Affairs v. Teoh, (1995) 69 ALJR 423.

63 State v. Metro. Police Comm'r, 60 D.L.R. (2008). 660, at 665-6. 
the UNCRC, as is the mandate of that Convention upon the signatories. ${ }^{64}$

The Court opined that at all times the best interests of the child should be of paramount importance and since the Court is largely reliant on the report of the probation officer, it is desirable that the latter speak to the accused child in the manner prescribed by the UNCRC in Article 12 which states that

... the child shall in particular be provided the opportunity to be heard in any judicial and administrative proceedings affecting the child, either directly, or through a representative or an appropriate body, in a manner consistent with the procedural rules of national law. ${ }^{65}$

Emphasising the role of probation officers in ascertaining the factual aspects in terms of the family background and character of the accused child, the Court directed them to seek the views of the concerned child and give them due weight in accordance with the age and maturity of the child.

In the case of Fahima Nasrin v. Bangladesh and Others, ${ }^{66}$ the High Court Division referred to the UNCRC (1989) in relation to the incarceration of child offenders and the possibility of taking children out of jail to be placed in a certified institute. It stressed that it is always possible to legally revert a child from prison to a certified home, which essentially reinforces the view that children should not ordinarily be sentenced to imprisonment, unless absolutely necessary and in exceptional circumstances, and that too as a matter of last resort and for the shortest period of time. The Court emphasised that laws relating to children were special laws, enacted for their well-being. Recognising that children commit offences under the influence of a host of factors not all of which can be attributed to their own fault, the Court observed that

... [i]t is very easy to say that that a child has committed a serious offence and must be severely dealt with and be sent to prison for the protection of the public, but under the laws of our country as well as international instruments, covenants and norms, it is also our duty to ensure that we act with equanimity when dealing with

$64 \quad I d$. at 668 .

65 Convention on the Rights of the Child, Nov. 20, 1989, 1577 U.N.T.S. 3.

66 Fahima Nasrin v. Bangladesh, 61 DLR (2009) (HCD) 232. 
cases of children ... They are to be given all the benefits that our Constitution and the laws of the land provide for them. We are also obliged to implement various beneficial provisions of international conventions, covenants and treaties such the Convention on the Rights of the Child (UNCRC) and the International Covenant of Civil and Political Rights, to which Bangladesh is a signatory ... [T] he rights of the child are not only protected by the Children Act 1974, but are [also] mandated by the UNCRC. Above all, the favourable provision of the law and the covenants and conventions are to be applied [for] the benefit of the child as provided by Article 28(4) of the Constitution ... ${ }^{67}$

The Court stressed on the need to avoid retributive measures and instead create for children a congenial environment within which to develop, keeping in mind at all times the welfare and best interests of the child.

In the case of State v. Secretary, Ministry of Law, Justice and Parliamentary Affairs and Others, ${ }^{68}$ a 7-year-old girl, a victim of rape by her neighbor, was sent to a safe home run by the Department of Social Welfare of the government. In a suo motu rule by the High Court Division, it was observed that the learned judge should have realised that it would be inhuman to separate a 7 year old girl who was brutally raped from her parents, who would be better at giving her the necessary care and protection than a government run safe home. Referring to Article 12 of the CRC, the Court held that the provisions of international instruments to which Bangladesh is a signatory should be implemented. The Court also referred to Article 3 of the CRC and stated:

[Had] the best interests of the child been considered ... then the seven year old [would have been allowed to remain with her parents] ... . [Had] the learned Magistrate properly appreciated the law, then he could not have torn the girl away from her parents and sent her to safe custody in a safe home. ${ }^{69}$

The Court further observed:

There is nothing on record to suggest that the learned Magistrate at all considered the views of the child which shows abject ignorance

\footnotetext{
$67 \quad I d$. at 242.

68 State v. Sec'y, Ministry of Law, Justice and Parliamentary Affairs and others, 29 BLD (2010) 656.

69 Id. at 670.
} 
of the international provisions, which are meant...for the welfare and well being of children. Moreover, the tearing away of a seven year old female child from the bosom of her mother can be nothing other than cruel and inhuman treatment which is contrary to Article 27 of the CRC as well as Article 35(5) of our Constitution. ${ }^{70}$

\section{CHILD LABOUR}

In Bangladesh National Women Lawyers Association (BNWLA) v. Cabinet Division, Bangladesh Secretariat, and Others, ${ }^{71}$ the Court observed that domestic work with all the hazards of working with dangerous implements and fire, as well as working long hours, would be classified as hazardous work, especially when children aged less than 12 years are involved. The Court alluded to the provisions of ILO Convention No. 182, which Bangladesh ratified in 2001. In the present case, the Petitioner brought to the attention of the Court a newspaper story about the maltreatment of a child housemaid aged 10 years by the lady of the house who tied up the child, pushed her to the floor, and inserted the handle of a hot cooking utensil (stirrer/paddle) into her anus. The girl was in a critical condition, receiving treatment at the Dhaka Medical College Hospital. The report also describes how the girl who was sent to work by her father was subjected to routine torture on the slightest of pretexts.

In Ain O Salish Kendra (ASK) v. Bangladesh and others, ${ }^{72}$ pursuant to stories in local newspapers describing the plight of children between the ages of 8-16 years engaged in bidi (hand-rolled cigarette)factories in Haragacha, Rangpur, the Petitioners filed a writ seeking an order from the Court declaring the continuous failure of the Respondents to ensure a healthy, hygienic, and safe work place for the workers in the concerned bidi factories as illegal and unconstitutional, being a violation of the fundamental rights guaranteed under Articles 27 and 31 of the Constitution, and why they should not be directed to discharge their legal duties to ensure compliance with relevant labour laws. The Petitioner highlighted the unhealthy and unhygienic conditions under which workers, including children, worked in these factories, inhaling air polluted by tobacco dust, and how large

\footnotetext{
$70 \quad I d$. at 671.

71 Bangladesh National Women Lawyers Association (BNWLA) v. Cabinet Division, Bangladesh Secretariat, 31 BLD 265 Writ Petition No. 3598 of 2010.

72 Ain O Salish Kendra (ASK) v. Bangladesh and others, 31 BLD (2011) (HCD) 36.
} 
quantities of nicotine were detected in their blood systems. They also maintained that many workers were afflicted with various chronic diseases such as asthma, tuberculosis, jaundice, bronchitis, kidney infections, and skin and eye diseases. The Petitioners also pointed out that the workers in these factories earned a meagre 13.50 taka (US\$ 0.19 approximately) for making one thousand bidi-sticks. They also flagged the opinions of the local chest hospital which revealed that about 30 workers had died in the last five years after contacting tuberculosis and bronchitis, among whom seven were children. The learned Court observed that children's concerns were not given priority by relevant state agencies in the way they should, given that children comprise more than forty percent of the country's population. The Court conceded that while the law requires that children's cases should be heard frequently, this is not done in practice. The Court recalled the suggestion made in the case of State v. Secretary, Ministry of Law Justice and Parliamentary Affairs and others ${ }^{73}$ where it was recommended that at least one Court in every district dedicated to hear children's cases should be established on a priority basis and that in consonance with promises made by Bangladesh to the Committee of the CRC, a Children's Ombudsman/ Children's Commissioner/National Juvenile Justice Forum should be set up. Taking into consideration all such matters, the Court suggested that those parents who, due to their financial condition, are compelled to send their children to work must be targeted, identified, and assisted as mandated by the Constitution and the CRC. Besides, children who are compelled to work due to food insecurity and poverty should be provided a free meal and all necessary expenses for attending school as well as an income to be paid to the parents equivalent to the income likely to be earned by the child had s/he not attended school. Referring extensively to relevant provisions of the Convention on the Rights of the Child (CRC) (1989) and the ILO Convention C182 Worst Forms of Child Labour Convention (1999), the Court observed that it is now well established that the provisions of international instruments to which Bangladesh is a signatory are to be implemented in our domestic laws. Reiterating decisions in Hussain Mohammad Ershad v. Bangladesh \& others ${ }^{74}$ and State v. Metropolitan Police

73 State v. Sec'y, Ministry of Law, Justice and Parliamentary Affairs and others, 29 BLD (AD) (2010) 656.

74 Hussain Muhammad Ershad v. Bangladesh, 21 BLD (2001) 69. 
Commissioner, ${ }^{75}$ the Court emphasised that obligations under international law should not be ignored.

\section{b. Sexual Harassment of Women and Girls}

Women's issues in Bangladesh (family disputes, violence against women, etc.) are predominantly settled under the auspices of the personal laws, criminal laws or special laws, as the case may be. Activism by women's groups and human rights defenders surrounding an alarming rise in sexual harassment of women and girls in public places, at work, and learning centers culminated in judicial recognition of the urgency for effective laws and policies to prevent the phenomenon. In the case of Bangladesh National Women Lawyers Association (BNWLA) v. Government of Bangladesh and Others, ${ }^{76}$ a rule nisi was issued calling upon the Respondents to show cause as to why the Respondents failed to adopt guidelines, or policy or enact proper legislations to address the issue of sexual harassment of women and girl children at work place, educational institutions/universities and other places, despite wide media coverage of the occurrence almost on a regular basis. The Petitioner drew the attention of the Court to a number of incidents as reported by the media and evidence based scholarly work on the subject in order to press home their concern over the issue. The Court opined that the fundamental rights guaranteed in the Constitution of Bangladesh sufficiently addresses elements of gender equality including prevention of sexual harassment or abuse. Besides, in the absence of any domestic law applicable in a particular context, international conventions and norms are to be drawn upon to supplement the fundamental rights. The Court observed that it is an accepted rule of judicial construction to interpret municipal law in conformity with international law and conventions when there is a void in the domestic law and when there is no inconsistency between them. The Court underscored the significance of international conventions and norms in the formulation of guidelines address sexual

\footnotetext{
75 State v. Metro. Police Comm'r, 60 D.L.R. (2008) 660.

76 Bangladesh National Women Lawyers Association (BNWLA) v. Bangladesh, Writ Petition No. 5916 (2008) (or WP No. 5916 of 2008).
} 
harassment adding that the rights to education and work with dignity are basic human rights and have accordingly received global acceptance.

The Court referred to the relevant provisions of the Universal Declaration on Human Rights (UDHR), Covenants on Civil and Political Rights (ICCPR) and Economic, Social and Cultural Rights (ICESCR), and the Declaration on the Elimination of Violence against Women, and reiterated Bangladesh's obligations under them. It also recalled Article 25 of the Constitution of Bangladesh which states, inter alia, that the State shall base its international relations on the principles of respect for international law and the principles enunciated in the United Nations Charter. ${ }^{77}$ The Court conceded that Bangladeshi courts do not normally invoke international covenants, treaties and conventions, even if ratified by the State, unless those are incorporated in the municipal legislation. However, the court can rely upon these conventions and covenants to aid their interpretation of the provisions of the Constitution, particularly in the determination of the rights to life liberty. It alluded to other case law on the use and interpretation of international legal principles to explain its position.

In conclusion, the Court recognized the inadequacy of safeguards against sexual abuse and harassment of women at work places and educational and issued certain directives, in the form of guidelines, to be observed at all work places and educational institutions until adequate and effective legislation is enacted.

\section{c. Right to Life}

Courts in Bangladesh generally rely on constitutional provisions when addressing issues involving the right to life. However, there are a couple of instances where the court proactively alluded to international law in arriving at a decision. In Professor Nurul Islam and others v. Government of the People's Republic of Bangladesh ${ }^{78}$ the Petitioners moved against promotional campaigns and advertisements of tobacco products. They maintained that although tobacco companies were seen as complying with statutory warnings on billboards or packets, the script was often too small that it is not readable easily. Besides, they alleged that such messages, even if legible, would have no impact on rural populations, including women

77 BAngl. Const., art. 25.

78 Nurul Islam v. Bangladesh, 52 DLR (2000) (HCD) 413. 
and children, who were predominantly illiterate. The Court held that such advertisements were detrimental to the lives and bodies of people according to Article 31 of the Constitution. It opined that Article 25(1) of the Constitution casts an obligation upon the state to have respect for international law and the principles enunciated in the United Nations Charter and World Health Organization resolution; accordingly, the government should have taken appropriate steps to ban/restrict such promotional activities.

In Bangladesh Legal Aid and Services Trust (BLAST) and another v. Bangladesh and others, ${ }^{79}$ the Court on being confronted with the issue of mandatory penalty for the convicted, considered both the Petitioner's point of view that Bangladesh was a signatory to the ICCPR and as such, its provisions should be applied in considering the death penalty vis-à-vis the Constitution, and the submission of the Attorney General who maintained that the provisions of international instruments are not applicable since they have not been incorporated in national laws. In the final assessment, the learned Court observed that there was virtually no conflict in this regard given that the provisions in Article 5 of the Universal Declaration of Human Rights and Article 7 of ICCPR respectively have been reproduced almost verbatim in Article 35(5) of our Constitution which provides that "no person shall be subjected to torture or to cruel, inhuman, or degrading punishment or treatment." 80

\section{d. Freedom from Torture}

In the case of Salma Sobhan v. Government of Bangladesh, ${ }^{81}$ the High Court Division recognised that the practice of chaining prisoners with bar fetters amounted to cruel, degrading, and inhumane punishment, and as such, a violation of fundamental rights. While the Court did not explicitly refer

79 Bangladesh Legal Aid and Serv. Trust v. Bangladesh, Writ Petition No. 8283 of 2005.

80 Bangl. Const., art. 35(5).

81 Salma Sobhan v. Government of Bangladesh, Writ Petition No. 2678 of 1995 (unreported), in Ridwanul, supra note 21, at 163. 
to international human rights law against torture, its observation in this regard nonetheless appears to have been largely influenced by it.

In Bangladesh Legal Aid and Services Trust v. Bangladesh, ${ }^{82}$ the Petitioners brought to the attention of the Court the matter of public beating, caning, flogging, etc. of women pursuant to fatwas (pronouncements) declared by religious/community leaders for apparently transgressing social norms. The Court declared that the failure of the State to take any systematic action to address extra-judicial punishments amounts to a breach of its obligation under both the Constitution and international law. Recognizing that the prohibition of torture and other ill treatment is a basic principle of customary international law, the Court went on to elaborate that Bangladesh has an obligation under international law to prevent, prohibit, and punish torture and other cruel, inhuman, and degrading treatment or punishment. Although mindful of the fact that the national courts shall not enforce international law instruments unless they are incorporated in the municipal laws, the Court nonetheless affirmed that these conventions and covenants can be used to interpret fundamental freedoms envisaged in the Constitution.

\section{e. Citizenship}

In a citizenship matter before it, the Appellate Division of the Supreme Court made a rare departure from the usual practice of conservatism in respect of international human rights law. In Bangladesh v. Prof. Golam $A z a m,{ }^{83}$ the Court relied on some provisions of the Convention on the Reduction of Statelessness (1961) in arriving at a decision despite the fact that Bangladesh is not a party to the Convention.

It is evident from the above cases that with a few exceptions, judges generally tend to use international human rights law primarily to analyze ambiguities inherent in the national laws. Consequently, their reliance on international human rights law has largely remained confined to merely

82 Bangladesh Legal Aid and Services Trust v. Bangladesh, Writ Petition No. 5863 of 2009, Writ Petition No. 754 of 2010, and Writ Petition No. 4275 of 2010, available at http://www.humanrights.asia/countries/bangladesh/cases/Judgment\%20on\%20 Fotwa\%20and\%20illegal\%20punishment-ejp-judgment-8July2010.pdf.

Bangladesh v. Golam Azam, 46 DLR (AD) (1994) 194. 
embellishing their judgments with perfunctory references to international sources.

\section{CONCLUSION: ENSURING PRIMACY OF INTERNATIONAL HUMAN RIGHTS LAW OVER POLITICAL CONSIDERATIONS}

The fact that domestic courts are not obliged to apply international law directly operates as the single greatest limitation to national enforcement of international law. In the absence of such obligation, the decision whether courts shall give direct effect to international law is primarily a political and normative choice, both for states and their courts. ${ }^{84}$ In the context of Bangladesh, the status of international law in the domestic jurisdiction remains weak in the absence of a clear incorporating mechanism. Despite recommendations by various international treaty bodies, very few treaties that have been ratified have received vetting by the Parliament for codification into domestic law. ${ }^{85}$ Indeed, the decision to initiate reforms in the area largely rests on the political will of the lawmakers and the independence and astuteness of the judges.

It has been suggested that "limits should be imposed upon the domestic legislative processes to make sure that the result of those processes consists of all measures necessary for the implementation of human rights consecrated by international law, or for the improvement of those rights." 86 Therefore, once a treaty is concluded, States Parties are expected to ensure that all or at least some of its provisions are enforced by their domestic courts. This is particularly true of human rights treaties, provisions of which are reiterated in most national constitutions and as such, are en-

84 See generally D. Kennedy, A Critique of Adjudication: (Fin de Siècle) 40 (1998); B. de Sousa Santos, Toward a New Common Sense: Law, Science and Politics in the Paradigmatic Transition 114 (1995).

85 Bianca Karim \& Tirza Theunissen, Bangladesh, in International LaW and Domestic Legal Systems: Incor poration, Transformation, and Persuasion 115 (Dinah Shelton ed. 2011).

86 Ximena Fuentes Torrijo, International Law and Domestic Law: Definitely an Odd Couple, 77 Revista Juridica Universidad de Puerto Rico 483 (2007), available at http://www.law.yale.edu/documents/pdf/sela/XimenaFuentes_English_.pdf. 
forceable in national courts. As noted by the Committee on Economic, Social and Cultural Rights:

In general, legally binding international human rights standards should operate directly and immediately within the domestic legal system of each State party, thereby enabling individuals to seek enforcement of their rights before national courts and tribunals. The rule requiring the exhaustion of domestic remedies reinforces the primacy of national remedies in this respect. The existence and further development of international procedures for the pursuit of individual claims is important, but such procedures are ultimately only supplementary to effective national remedies. ${ }^{87}$

Indeed, state practice demonstrates that it is common for national law to regard international human rights law differently from other international laws. For example, the Canadian experience shows that Canadian law applies international human rights law differently than other international laws, for instance, international trade law, primarily because of (a) the universality of human rights, (b) the existence of a rights-protecting instrument within Canadian law, and (c) the perceived priority of human rights over other areas of law. ${ }^{88}$ In the Canadian jurisprudence, since basic rights and fundamental freedoms inhere in the human person, they are universal and signify the legal implication of being human. As such, it would be misleading to determine the relevance of human rights instruments simply on the basis of whether they are binding or non-binding upon a state.

That human rights have a pre-eminence over other rights is also manifest from the Bangalore declarations ${ }^{89}$ which underscore the determination of eminent judges from common law jurisdictions to give international human rights norms priority in their domestic adjudications. The 1988 Bangalore declaration affirms that "international human rights instruments provide important guidance in cases concerning human rights and fundamental freedoms" and recognizes that it is within the "well-established judicial functions for national courts to have regard

87 U.N. Comm. on Econ., Soc. \& Cultural Rights (CESCR), General Comment 9, 9 4 U.N. Doc. E/C.12/1998/24 (Dec. 3, 1998).

88 ERT, supra note 17, at 233.

89 The declarations were the outcome of a series of annual meetings of leading American and Commonwealth judges that began with the Bangalore Judicial Colloquium in 1988. 
to international obligations" of a country "whether or not they have been incorporated into domestic law - for the purpose of removing ambiguity [sic] from national constitutions, legislation or common law." ${ }^{90}$ The 1998 Bangalore declaration reads:

[T] he universality of human rights ... transcends national political systems and is in the keeping of the judiciary .... It is the vital duty of an independent, well-trained legal profession, to interpret and apply national constitutions and ordinary legislation in harmony with international human rights codes and customary international law...even where human rights treaties have not been ratified or incorporated into domestic law, they provide important guidance to lawmakers, public officials and the courts. ${ }^{91}$

Clearly, "there is nothing to deter courts from considering international human rights instruments in construing domestic rights provisions because international provisions are an expression of a conception of humanity subscribed to by the state and reflected in national human rights law provisions." ${ }^{2}$ As such, judges in Bangladesh can use their discretion to choose selectively from the wide array of international human rights standards to link international law obligations to the domestic legal system when adjudicating cases. It has been suggested that judges can exercise their discretion in a number of ways: "by interpreting treaties, by ordering treaty obligations in a hierarchical order, by 'finding' customary international law, and by determining which of these norms is directly applicable within the domestic legal system and how they interact with domestic norms." 93 While recent judicial decisions signify a shift in the attitude of Bangladeshi judges regarding the value of international human rights law, their approach to international sources can still be termed as conservative; this conservatism appears to be "deeply influenced by its orthodox comprehension of its

90 ERT, supra note 17, at 237.

$91 \quad$ Id. at 238.

92 Id. at 235.

93 Eyal Benvenisti \& George W. Downs, National Courts, Domestic Democracy, and the Evolution of International Law, 20 European Journal of InternationaL LAW 59, 60 (2009). 
own constitutional role in invoking international human rights." ${ }^{4}$ In the majority of cases, judges fail to recognize that certain human rights are so fundamentally universal that the treaties containing such norms can effectively be construed as self- executing. Besides, given that the fundamental rights envisaged in the Bangladesh Constitution essentially reiterate many international human rights norms, it is a judicial duty to recognize that the invocation of these universal standards is not only "constitutionally feasible but also to some extent obligatory." 95

It has been observed that a judiciary that is independent of the national Government that employs international standards by resorting to technical, non-political, legal discourse, has the potential to interpret, apply, and develop international norms. ${ }^{96}$ However, in Bangladesh, judges are constrained by various factors that essentially inhibit them from the innovative use of international human rights law, particularly if its invocation directly conflicts with the will of the executive. Increased politicization of the judiciary has effectively eroded its independence and apolitical status. Judicial deference to the political executive is manifest from the rigid interpretation of constitutional provisions on, for example, the right to life and liberty, freedom of expression, equality before law, etc. Arguably, the very existence of the judicial system is to secure for citizens legal rights and protect them against arbitrary use of political and economic power. Unfortunately, Bangladeshi courts have over the years become vulnerable to partisan political pressure, and as such, tend to serve political interests rather than engage in innovative legal discourse. Resultantly, judicial decisions are crafted so as not to upset government interests. While progressive judicial thinking essentially hinges on the intellectual capacity, creativity, and foresightedness of the judges, this is largely circumscribed by political appointments to judicial positions of individuals who lack the requisite qualifications and experience. Many of them have no knowledge of international legal resources, and even if they had, are unwilling to use

\footnotetext{
94 Ridwanul Hoque, Judicial Activism in Bangladesh: A Golden Mean APPROACH 224 (2011).

$95 \quad I d$.

96 Eyal Benvenisti, Judicial Misgivings Regarding the Application of International Law: An Analysis of Attitudes of National Courts, 4 European Journal of INTERNATIONAL LAW 159, 160 (1993).
} 
them if they think that it might displease the political executive. This has far reaching consequences on the manner in which they adjudicate cases and their outcomes. The politicization of the judiciary has thus minimized judicial accountability, impeded judicial activism, and rendered public interest ineffective-all of which retard progressive judicial learning. 